\title{
Cover Crop Management in a Chardonnay/99 Richter Vineyard in the Coastal Wine Grape Region, South Africa. 1. Effect of Two Management Practices on Selected Grass and Broadleaf Species
}

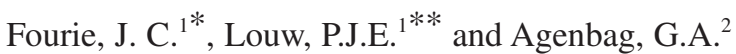

(1) ARC Infruitec-Nietvoorbij, Private Bag X5026, 7599 Stellenbosch, Republic of South Africa

(2) Department of Agronomy, University of Stellenbosch, 7600 Stellenbosch, Republic of South Africa

Submitted for publication: August 2006

Accepted for publication: September 2006

Key words: Cover crops, re-establishment, management practices, weed control, grapevines.

\begin{abstract}
The trial was conducted over a period of 10 years $(1993 / 94$ to $2002 / 03)$ on a medium textured soil in a Chardonnay/99 Richter vineyard near Stellenbosch (33'55'S, $1^{\circ} 5^{\circ}$ 'E), situated in the Coastal Wine Grape Region of the Western Cape. Sixteen treatments, consisting of three grain species and five N-fixing broadleaf species managed according to two cover crop management practices, were included. These treatments were compared to a control treatment, in which no cover crop was sown and the weeds were controlled mechanically in the work row and chemically in the vine row from the first week of September to the end of March (grapevine growing season). A treatment in which no cover crop was sown and full surface post-emergence chemical control was applied during the grapevine growing season was also included. The different weed control actions were carried out during the first week of September and/or at the end of November, as well as mid October (1999/00 to 2002/03). Secale cereale $\mathrm{L}$. v. Henog (rye), Avena sativa L. v. Overberg ('Overberg' oats), Avena strigosa L. v. Saia ('Saia' oats) and Vicia faba L. v. Fiord [only if sown annually and controlled chemically before bud break (BB)], showed the ability to produce, on average, significantly more dry matter during winter than the weeds in the region. The dry matter production of all the cover crops increased from the end of August to the end of November if left to complete their life cycles, with the exception of rye and 'Overberg' oats sown in early April. None of the cover crop species were able to reestablish successfully. Continuous effective suppression of winter growing weeds (less than $20 \%$ of the weed stand in the control) was achieved with 'Overberg' oats (BB) and 'Saia' oats (BB), while total suppression was achieved for six and five of the $\mathbf{1 0}$ years, respectively. Effective, long-term control of the summer growing weeds was obtained with rye (BB), 'Overberg' oats (BB) and 'Saia' oats (BB).
\end{abstract}

An increasing number of weed species are developing resistance to herbicides and even to groups of herbicides with different modes of action (Anonymous, 1997; Henkes, 1997; LeBaron, 1991). Certain weed species can be controlled with biological agents (Cullen et al., 1973; Daniel et al., 1973; Phatak et al., 1983; Woodhead, 1981). The vacated niche will, however, be filled by other species not susceptible to the agent (Putnam, 1990). Cover crop management is a non-specific biological method of pre-emergence weed control, which has many advantages (Buckerfield \& Webster, 1996; Khan et al., 1986, Louw \& Bennie, 1992; Radcliffe et al., 1988; Roth et al., 1988; Van Huyssteen et al., 1984).

The difference in climate between regions, as well as the spectrum of winter growing weeds in a specific region, has an effect on the performance of a cover crop species (Fourie et al., 2001). A selection of species suitable for cover crop management in the different grapevine regions is required in order to apply this environment friendly practice in a sustainable manner, as part of an integrated production strategy (Fourie et al., 2001). In this regard it was indicated that Secale cereale L. (rye), two Avena (oat) species and Triticale v. Usgen 18 (triticale) could be considered for cover crop management on the medium textured soils of the Coastal wine grape region, situated in the winter rainfall region of South Africa (Fourie et al., 2001). They also indicated that three Trifolium subterraneum (subterranean clover) species, four Medicago (medic) species, three Vicia (vetch) species and Ornithopus sativus L. v. Emena (pink Seradella) should be included in further studies to determine whether the norm of eight t/ha of dry matter, considered by Van Huyssteen et al. (1984) to be necessary for the effective control of summer growing weeds, was applicable to these species under the edaphic conditions of the Coastal region.

This study was carried out to determine the effect of two cover crop management practices on eight selected cover crop species, with the objective of supplying the wine grape industry with guidelines for sustainable cover crop management in vineyards established on medium textured soils in the Coastal wine grape region.

\footnotetext{
**Present address: EXSA, P.O. Box 1000, 7599 Stellenbosch, Republic of South Africa.

*Corresponding author: E-mail address: FourieJ@arc.agric.za

Acknowledgements: The authors thank the ARC and Winetech for financial support, as well as the staff of the Soil Science Section of ARC Infruitec-Nietvoorbij for technical support. This study is part of a Ph.D. (Agric) dissertation at the University of Stellenbosch.
} 


\section{MATERIALS AND METHODS}

\section{Experiment vineyard and layout}

The trial was carried out in a Chardonnay/99 Richter vineyard trained on a seven-strand double-lengthened Perold trellis system (Booysen et al., 1992) and established on a medium textured soil (see Table 1) at the Nietvoorbij research farm near Stellenbosch during November 1992. The soil used in the trial is representative of the top soil of medium textured soils found in the vineyards of the Coastal wine grape region of the Western Cape. Stellenbosch $\left(33^{\circ} 55^{\prime} \mathrm{S}, 18^{\circ} 52^{\prime} \mathrm{E}\right)$ is situated in the Coastal wine grape region of the Western Cape. Mean annual rainfall amounts to $705 \mathrm{~mm}$, of which approximately $73 \%$ precipitates during the autumn and winter (March to August). The vines were spaced $1.5 \mathrm{~m}$ in the row and $2.75 \mathrm{~m}$ between rows. The soil was analysed for $\mathrm{pH}(1.0$ $\mathrm{M} \mathrm{KCl}$ ), $\mathrm{P}$ and $\mathrm{K}$ (Bray II), exchangeable $\mathrm{K}, \mathrm{Ca}, \mathrm{Mg}$ and $\mathrm{Na}$ (extracted with $0.2 \mathrm{M}$ ammonium acetate) and organic carbon by means of the Walkley-Black method (The Non-affiliated Soil Analysis Work Committee, 1990). These analyses were done during March 1993 for the 0-300 mm and 300-600 mm soil layers, before the treatments were initiated (see Table 1). The $\mathrm{pH}$ and $\mathrm{P}$ (Bray II) analyses were repeated during March 1997 and March 2000 on the $0-300 \mathrm{~mm}$ soil layer (see Table 2).

Eighteen treatments were applied as shown in Table 3. Two cover crop management practices, namely full surface post-emer-

\section{TABLE 1}

Analyses of the medium textured soil near Stellenbosch determined before the treatments commenced (sampled March 1993).

\begin{tabular}{|c|c|c|c|c|c|c|c|c|c|c|c|c|}
\hline \multirow[t]{2}{*}{ Soil depth (mm) } & \multirow[t]{2}{*}{$\begin{array}{l}\text { Clay } \\
(\%)\end{array}$} & \multirow[t]{2}{*}{$\begin{array}{l}\text { Silt } \\
(\%)\end{array}$} & \multirow[t]{2}{*}{$\begin{array}{c}\text { Sand } \\
(\%)\end{array}$} & \multirow[t]{2}{*}{$\underset{(\mathbf{K C l})}{\mathbf{p H}}$} & \multirow{2}{*}{$\begin{array}{c}\text { Electrical } \\
\text { conductivity } \\
(\mathrm{mS} / \mathrm{m})\end{array}$} & \multirow{2}{*}{$\begin{array}{c}\text { Organic } \\
\text { C } \\
(\%)\end{array}$} & \multirow[t]{2}{*}{$\underset{(\mathbf{m g} / \mathbf{k g})}{\mathbf{P}}$} & \multirow[t]{2}{*}{$\underset{(\mathbf{m g} / \mathbf{k g})}{\mathbf{K}}$} & \multicolumn{4}{|c|}{$\begin{array}{c}\text { Exchangeable } \\
\text { cations }(\mathrm{cmol}(+) / \mathrm{kg})\end{array}$} \\
\hline & & & & & & & & & $\mathrm{Ca}$ & Mg & $\mathbf{K}$ & $\mathbf{N a}$ \\
\hline $0-300$ & 17.06 & 12.68 & 70.26 & 6.3 & 20 & 0.53 & 22 & 111 & 3.56 & 0.33 & 0.30 & 0.04 \\
\hline $300-600$ & 18.73 & 14.06 & 67.21 & 6.5 & 19 & 0.41 & 15 & 51 & 3.28 & 0.38 & 0.16 & 0.06 \\
\hline
\end{tabular}

TABLE 2

Phosphorous concentration and $\mathrm{pH}$ in the $0-300 \mathrm{~mm}$ soil layer of the medium textured soil near Stellenbosch, as measured at the end of February 1993, 1997 and 1999.

\begin{tabular}{|c|c|c|c|c|c|c|c|c|}
\hline \multirow{2}{*}{ Treatment } & \multicolumn{2}{|c|}{1993} & \multicolumn{3}{|c|}{1997} & \multicolumn{3}{|c|}{1999} \\
\hline & $\mathbf{p H}(\mathrm{KCl})$ & $\mathbf{P}(\mathbf{m g} / \mathrm{kg})$ & $\frac{0-300 \mathrm{~mm}}{\mathrm{pH}(\mathrm{KCl})}$ & $\frac{0-150 \mathrm{~mm}}{P(\mathrm{mg} / \mathrm{kg})}$ & $\frac{150-300 \mathrm{~mm}}{P(\mathrm{mg} / \mathrm{kg})}$ & $\frac{0-300 \mathrm{~mm}}{\mathrm{pH}(\mathrm{KCl})}$ & $\frac{0-150 \mathrm{~mm}}{P(\mathrm{mg} / \mathrm{kg})}$ & $\frac{150-300 \mathrm{~mm}}{P(\mathrm{mg} / \mathrm{kg})}$ \\
\hline \multicolumn{9}{|l|}{ Grain species: } \\
\hline Secale cereale L. v. Henog (rye), $\mathrm{BB}^{1}$. & 6.5 & 23 & 5.9 & 16 & 11 & 5.7 & 31 & 24 \\
\hline Secale cereale $\mathrm{L} . \mathrm{v}$. Henog (rye) $\mathrm{AB}^{2}$. & 6.8 & 23 & 6.1 & 19 & 10 & 5.9 & 30 & 22 \\
\hline Avena strigosa L. v. Saia ('Saia’ oats), BB. & 6.5 & 23 & 5.9 & 19 & 9 & 5.8 & 29 & 32 \\
\hline Avena strigosa L. v. Saia ('Saia' oats), AB. & 6.6 & 22 & 6.2 & 23 & 18 & 6.0 & 27 & 26 \\
\hline \multicolumn{9}{|l|}{ N-fixing broadleaf species: } \\
\hline Vicia dasycarpa Ten. (grazing vetch), BB. & 6.8 & 26 & 6.3 & 19 & 10 & 6.1 & 26 & 26 \\
\hline Vicia dasycarpa Ten. (grazing vetch), AB. & 6.8 & 22 & 6.3 & 15 & 10 & 6.1 & 28 & 27 \\
\hline $\begin{array}{l}\text { Medicago truncatula Gaertn v. Paraggio } \\
\text { ('Paraggio' medic), AB. }\end{array}$ & 6.8 & 30 & 5.9 & 21 & 16 & 5.8 & 26 & 28 \\
\hline $\begin{array}{l}\text { Medicago scutellata (L.) Mill. v. Kelson } \\
\text { ('Kelson' medic), BB. }\end{array}$ & 6.3 & 27 & 6.0 & 18 & 9 & 5.9 & 32 & 20 \\
\hline $\begin{array}{l}\text { Medicago scutellata (L.) Mill. v. Kelson } \\
\text { ('Kelson' medic), AB. }\end{array}$ & 6.8 & 27 & 6.1 & 18 & 14 & 5.7 & 30 & 18 \\
\hline $\begin{array}{l}\text { Trifolium subterraneum } \mathrm{L} \text {. v. Woogenellup } \\
\text { ('Woogenellup' subterranean clover), BB. }\end{array}$ & 6.8 & 25 & 6.0 & 15 & 11 & 5.8 & 24 & 24 \\
\hline $\begin{array}{l}\text { Trifolium subterraneum L. v. Woogenellup } \\
\text { ('Woogenellup' subterranean clover), AB. }\end{array}$ & 6.9 & 25 & 5.9 & 20 & 15 & 6.0 & 30 & 24 \\
\hline $\operatorname{LSD}(\mathrm{p} \leq 0.05)$ & $\mathrm{NS}^{3}$ & NS & NS & 9 & 7 & NS & NS & NS \\
\hline
\end{tabular}

${ }^{1} \mathrm{BB}=$ full surface post-emergence chemical control from just before bud break. ${ }^{2} \mathrm{AB}=$ full surface chemical control from the end of November (1993 to 1998 ) and from mid October (1999 to 2002). ${ }^{3}$ Data do not differ significantly on the 5\% level. 
gence chemical control from the first week in September (bud break) to the end of March (BB), which is the growing season of the grapevines, and full surface post-emergence chemical control from the stage when the berries reached pea size at the end of November to the end of March (AB), were applied to eight cover crop species. These treatments were compared to a control treatment, in which no cover crop was sown and the weeds were controlled mechanically in the work row and chemically in the vine row over the period from bud break to the end of March. A treatment in which no cover crop was sown and full surface postemergence chemical control was applied during the growing season of the vines (weeds, BB) was also included. Weed control was carried out twice yearly, namely just before bud break and at the end of November. From 1999 to 2002 all the species in the AB treatments were controlled chemically during mid-October. Postemergence weed control was applied with glyphosate at a rate of $1.44 \mathrm{~kg} / \mathrm{ha}$ by means of a tractor sprayer.

The vineyard was irrigated by means of $25.7 \mathrm{~L} / \mathrm{h}$ micro-sprinklers which had a $360^{\circ}$ wetting pattern. The micro-sprinklers were installed on the irrigation line in the upright position at 1.5 $\mathrm{m}$ intervals. Irrigation of the cover crops was scheduled as described by Fourie et al. (2001) for the first 10 weeks after sowing (April to mid-June). Following this period, the cover crops were dependent on the rainfall, which is normally ca. $109 \mathrm{~mm}$, $127 \mathrm{~mm}$ and $121 \mathrm{~mm}$ for June, July and August, respectively, in this region. The cover crops were sown annually in early April (seeding dates varying between 4-15 April) at seeding densities suggested by Fourie et al. (2001), with the exception of 1993 when infrastructural work delayed sowing until 24 May. Seedbed preparation was done with a disc harrow approximately six weeks before the seeding date. After sowing by hand, the seeds were covered using a rotary harrow. During 1995 and 1997, no seeds were sown in the $\mathrm{AB}$ treatments to determine if the species would be able to re-establish themselves, while during 1999 this management practice was restricted to the $\mathrm{N}$-fixing broadleaf species. From 2000 onwards, all the treatments were sown annually.

All the treatments received $14 \mathrm{~kg} / \mathrm{ha}$ of $\mathrm{N}$ during seedbed preparation, as well as at the two- to four-leaf development phases of the grass cover crops. In the case of the $\mathrm{N}$-fixing broadleaf cover crops, the $\mathrm{N}$ was applied to the vine row only, while in the other treatments it was broadcasted. From the 1998 season onwards, $19.5 \mathrm{~kg}$ of $\mathrm{P} / \mathrm{ha}$ was broadcasted over all treatments at

\section{TABLE 3}

Effect of two cover crop management practices on dry matter production (DMP) by three grain species and five N-fixing broadleaf species, measured at the end of August.

\begin{tabular}{|c|c|c|c|c|c|c|c|c|c|c|c|}
\hline \multirow[t]{2}{*}{ Treatment } & \multicolumn{11}{|c|}{ DMP (t/ha) } \\
\hline & $1993^{1}$ & 1994 & 1995 & 1996 & 1997 & 1998 & 1999 & 2000 & 2001 & 2002 & Average \\
\hline \multicolumn{12}{|l|}{ Grain species: } \\
\hline Secale cereale L. v. Henog (rye), $\mathrm{BB}^{2}$. & 1.37 & 5.13 & 4.56 & 5.51 & 3.42 & 3.90 & 1.53 & 3.22 & 2.22 & 2.38 & 3.32 \\
\hline Secale cereale L. v. Henog (rye), $\mathrm{AB}^{3}$. & 1.38 & 6.15 & $0^{5}$ & 8.50 & $0^{5}$ & 2.50 & 1.36 & 3.89 & 2.31 & 2.27 & 2.84 \\
\hline Avena sativa L. v. Overberg ('Overberg' oats), BB. & 2.24 & 9.49 & 6.48 & 7.23 & 4.48 & 4.48 & 2.09 & 3.38 & 3.60 & 5.19 & 4.87 \\
\hline Avena sativa L. v. Overberg ('Overberg' oats), AB. & 1.12 & 5.60 & $1.48^{5}$ & 7.21 & $0^{5}$ & 3.99 & 2.37 & 3.50 & 4.14 & 3.29 & 3.27 \\
\hline Avena strigosa L. v. Saia ('Saia’ oats), BB. & 0.97 & 6.13 & 4.83 & 5.90 & 4.13 & 3.98 & 2.08 & 2.79 & 3.26 & 3.44 & 3.75 \\
\hline Avena strigosa L. v. Saia ('Saia' oats), AB. & 1.50 & 4.71 & $0.62^{5}$ & 6.17 & $0^{5}$ & 2.71 & 2.52 & 3.38 & 3.66 & 3.65 & 2.89 \\
\hline \multicolumn{12}{|l|}{ N-fixing broadleaf species: } \\
\hline Vicia dasycarpa Ten. (grazing vetch), BB. & 1.10 & 3.71 & 2.51 & 2.45 & 0 & 0.45 & 1.05 & 2.43 & 0.05 & 0 & 1.38 \\
\hline Vicia dasycarpa Ten. (grazing vetch), AB. & 1.47 & 4.15 & $0.20^{5}$ & 2.35 & $0^{5}$ & 0.89 & $0.23^{5}$ & 4.22 & 0 & 0 & 1.35 \\
\hline Vicia faba L. v. Fiord (faba bean), BB. & 1.60 & 3.34 & 3.53 & 5.16 & 1.57 & 3.42 & 0.46 & 5.10 & 3.55 & 2.41 & 3.04 \\
\hline Vicia faba L. v. Fiord (faba bean), AB. & 2.57 & 3.26 & $0^{5}$ & 5.07 & $0.15^{5}$ & 3.56 & $0.79^{5}$ & 1.73 & 3.64 & 2.33 & 2.28 \\
\hline $\begin{array}{l}\text { Medicago truncatula Gaertn v. Paraggio } \\
\text { ('Paraggio' medic), BB. }\end{array}$ & 1.76 & 4.17 & 3.65 & 3.66 & 1.55 & 4.03 & 1.00 & 2.60 & 2.84 & 1.82 & 2.71 \\
\hline $\begin{array}{l}\text { Medicago truncatula Gaertn v. Paraggio } \\
\text { ('Paraggio' medic), AB. }\end{array}$ & 1.42 & 3.60 & $1.19^{5}$ & 2.23 & $0^{5}$ & 3.15 & $0.04^{5}$ & 1.73 & 2.22 & 1.41 & 1.70 \\
\hline $\begin{array}{l}\text { Medicago scutellata (L.) Mill. v. Kelson } \\
\text { ('Kelson' medic), BB. }\end{array}$ & 1.78 & 4.18 & 4.44 & 5.05 & 1.01 & 1.38 & 1.35 & 2.64 & 1.99 & 2.04 & 2.59 \\
\hline $\begin{array}{l}\text { Medicago scutellata (L.) Mill. v. Kelson } \\
\text { ('Kelson' medic), AB. }\end{array}$ & 2.14 & 4.01 & $0.20^{5}$ & 4.21 & $0.11^{5}$ & 1.33 & $0.38^{5}$ & 2.30 & 2.00 & 1.92 & 1.86 \\
\hline $\begin{array}{l}\text { Trifolium subterraneum L. v. Woogenellup } \\
\text { ('Woogenellup' subterranean clover), BB. }\end{array}$ & 0.79 & 2.01 & 1.25 & 1.14 & 0.37 & 0.30 & 0.67 & 2.69 & 2.00 & 1.50 & 1.27 \\
\hline $\begin{array}{l}\text { Trifolium subterraneum L. v. Woogenellup } \\
\text { ('Woogenellup' subterranean clover), AB. }\end{array}$ & 1.37 & 3.46 & $0^{5}$ & 1.64 & $0^{5}$ & 0.26 & $0^{5}$ & 2.11 & 2.15 & 1.38 & 1.24 \\
\hline Weeds, $\mathrm{MC}^{4}$ (Control). & 0.98 & 5.83 & 3.06 & 1.58 & 1.83 & 0.87 & 1.71 & 1.03 & 0.83 & 1.11 & 1.88 \\
\hline Weeds, BB. & 0.59 & 4.01 & 3.57 & 2.95 & 1.70 & 0.98 & 1.15 & 0.65 & 1.34 & 1.33 & 1.73 \\
\hline $\operatorname{LSD}(\mathrm{p} \leq 0.05)$ & 0.76 & 2.97 & 1.76 & 1.11 & $\mathrm{NS}^{6}$ & 0.74 & 1.04 & 1.90 & 1.47 & 0.99 & $\mathrm{NA}^{7}$ \\
\hline
\end{tabular}

${ }^{1}$ Cover crops established 24 May instead of early April. ${ }^{2} \mathrm{BB}=$ full surface post-emergence chemical control from just before bud break. ${ }^{3} \mathrm{AB}=$ full surface post-emergence chemical control from the end of November (1993 to 1998) and from mid October (1999 to 2002). ${ }^{4} \mathrm{MC}=\mathrm{chemical}$ control in vine row, mechanical control in working row. ${ }^{5}$ Cover crop left to re-establish. ${ }^{6}$ Data do not differ significantly on the $5 \%$ level. ${ }^{7}$ Not applicable 
the end of February, just before seedbed preparation. This was intended to restore and maintain the $\mathrm{P}$ concentrations in the 0 to $300 \mathrm{~mm}$ soil layer at approximately $30 \mathrm{mg} / \mathrm{kg}$ (see Table 2). This $\mathrm{P}$ concentration is the norm for grapevines established on these soils (Conradie, 1994), which is also the level that would help to ensure adequate growth rates with Medicago species (Sanderson, 1998). Calcitic lime was applied at a rate of $2.5 \mathrm{t} / \mathrm{ha}$ to the top soil layer at the end of February 2000, in order to enhance growth of the broadleaf species without exceeding the requirements for grapevines (W.J. Conradie, 2000 - personal communication). Dimethoate $(150 \mathrm{ml} / \mathrm{ha})$ was applied post-emergence to the two Medicago species and Vicia dasycarpa Ten. (grazing vetch) during 1999 in reaction to damage to the above-ground growth. From 2000 onwards the seeds of all the $\mathrm{N}$-fixing broadleaf species were treated with dimethoate $(600 \mathrm{~mL} / 100 \mathrm{~kg}$ seeds $)$ to protect the emerging seedlings.

\section{Measurements}

Dry matter production (DMP) by both the cover crops and the associated weeds was determined at the end of August and again at the end of November, according to the procedure described by Fourie et al. (2001). To determine the number of viable seeds present in the top $100 \mathrm{~mm}$ of the soil, including the seeds on the soil surface, a square quadrant with an area of $0.25 \mathrm{~m}^{2}$ was sampled at the end of February - six weeks before the seeding date. The soil was air dried and passed through an 850-micron sieve, to separate the organic matter and cover crop seeds from the soil. The cover crop seeds were then separated from the organic matter manually. The viability of the seeds was determined by means of the "between paper" method, prescribed by the International Seed Testing Association (1999).

\section{Statistical procedures}

The eighteen treatments were randomly allocated within each of three blocks. The design was an $(8 \times 2)+2$ factorial with factors eight cover crops, two management practices, as well as two other practices. The experiment was repeated for 10 consecutive seasons (years). The size of each unit (plot) was $165 \mathrm{~m}^{2}$. All variables were measured at random sites within each experiment unit at the end of August and end of November. Analyses of variance were performed for each season separately, using SAS (SAS, 1990). Student's $t$ least significant difference (LSD) was calculated at a $5 \%$ significance level to facilitate comparison between treatment means. The Shapiro-Wilk test was performed to test for non-normality (Shapiro \& Wilk, 1965).

\section{RESULTS AND DISCUSSION}

\section{Dry matter production of cover crops}

The DMP of the cover crop species in all the treatments, as measured before bud break (end of August), was lower during 1993 compared to that of the 1994 and 1996 seasons, the following two seasons during which the species were also established in all the treatments (see Table 3). This was attributed to the fact that the cover crops could only be sown as late as 24 May during 1993, compared to early April during 1994 and 1996. This supports the results of Fourie et al. (2001), indicating that these cover crops should be established before the second week of April in this region.

The long-term average DMP of the BB treatment of Avena sativa L. v. Overberg ('Overberg' oats) was the highest of all the treatments, and comparable to the values reported by Fourie et al. (2001) in a trial on open land. Although the long-term average DMP of the two Medicago species was less than that of the grain species, it was similar to production obtained on a sandy soil (Bolland, 1997; Fourie et al., 2005), but approximately 35\% less than production on open soil under similar edaphic conditions (Fourie et al., 2001). The long-term average DMP of grazing vetch and Trifolium subterraneum L. v. Woogenellup ('Woogenellup' subterranean clover) was less than that of the weeds in the control and the weeds (BB) treatment, indicating that it is risky to use these two species as cover crops under conditions similar to that of the trial.

Ignoring seasonal fluctuations in performance, the DMP of rye (BB) at the end of August declined progressively from the 1996 season onwards (see Table 3). The DMP in the BB treatments of the two Avena species showed a similar tendency to that observed in the BB treatment of rye. The decline in DMP was, however, more pronounced, and occurred especially from 1997 to 1999. The application of $\mathrm{P}$ from the 1998 season onwards did not result in a significant increase in the DMP of the grain species. The tendency to produce less dry matter in 1997 than in 1998 (see Table 3) was attributed to the much colder average daily temperatures in April 1997 and relatively low rainfall during July 1997 compared to that of 1998 (see Table 4). The poor performance of the grain species during 1999 as compared to that in 1998 and 2000 (see Table 2), could be attributed to the absence of rain in June 1999, followed by a relatively dry July (see Table 4). This supports the data of Van Bosch \& Pieterse (1995), who found that a reduction in the irrigation rate from $18 \mathrm{~mm}$ per week to $13 \mathrm{~mm}$ per week significantly reduced the DMP of rye, 'Overberg' oats and Avena strigosa L. v. Saia ('Saia' oats) by 1.2, 1.4 and $2 \mathrm{t} / \mathrm{ha}$, respectively. The application of calcitic lime at a rate of $2.5 \mathrm{t} / \mathrm{ha}$ during seedbed preparation in 2000 seemed to have improved the DMP of the grain species slightly, but only in the short term and not to the levels measured from 1994 to 1996 (see Table 3). The inability of the grain species to recover in full could have been caused by a gradual buildup of soil-borne diseases against these species as a result of the same species being sown year after year (Lamprecht et al., 1988; Lamprecht et al., 1990). This, however, was beyond the scope of this study. Overshadowing by the fullygrown grapevines in the period from harvest to leaf-fall might also have contributed to the observed decline.

The DMP of grazing vetch in the period from 1994 to 1996 was similar to that reported by Fourie et al. (2001) under similar edaphic conditions (see Table 3). From the 1997 season onwards, however, the performance of the species was exceptionally poor, except in the 2000 season. The application of $\mathrm{P}$ from 1998 onwards restored the level of $\mathrm{P}$ in the 0 to $300 \mathrm{~mm}$ soil level to approximately $30 \mathrm{mg} / \mathrm{kg}$ (see Table 3), which was more than sufficient to supply the needs of the species employed (De Ruiter, 1981). Despite this, the DMP of the species did not improve. The increase in DMP that occurred from 1998 to 1999 (see Table 3), despite the absence of rain in June 1999 (see Table 4), could be attributed to the post-emergence application of dimethoate in reaction to damage to the above-ground growth. The drastic increase in the DMP of grazing vetch from 1999 to 2000 was attributed to the application of $2.5 \mathrm{t} / \mathrm{ha}$ of calcitic lime during seedbed preparation, as well as to the seeds having been treated 
TABLE 4

Average daily temperature and monthly rainfall as measured near the trial site at Nietvoorbij Research Farm near Stellenbosch from April to August (Data supplied by ARC Institute for Soil, Climate and Water).

\begin{tabular}{|c|c|c|c|c|c|c|c|c|c|c|}
\hline Month & Measurement & 1994 & 1995 & 1996 & 1997 & 1998 & 1999 & 2000 & 2001 & 2002 \\
\hline \multirow[t]{2}{*}{ April } & Average daily temperature $\left({ }^{\circ} \mathrm{C}\right)$ & 19.5 & 17.7 & 18.2 & 15.9 & 17.9 & 17.9 & 18.2 & 17.6 & 17.7 \\
\hline & Total monthly rainfall (mm) & 59 & 23 & 53 & 60 & 37 & 59 & 14 & 50 & 65 \\
\hline \multirow[t]{2}{*}{ May } & Average daily temperature $\left({ }^{\circ} \mathrm{C}\right)$ & 14.5 & 16.5 & 15.3 & 15.0 & 14.5 & 15.0 & 15.1 & 15.2 & 14.0 \\
\hline & Total monthly rainfall $(\mathrm{mm})$ & 47 & 95 & 58 & 82 & 197 & 59 & 107 & 174 & 124 \\
\hline \multirow[t]{2}{*}{ June } & Average daily temperature $\left({ }^{\circ} \mathrm{C}\right)$ & 11.6 & 13.5 & 12.7 & 11.6 & 12.6 & 14.1 & 14.3 & 13.0 & 11.7 \\
\hline & Total monthly rainfall (mm) & 279 & 137 & 187 & 155 & 60 & 0 & 108 & 94 & 135 \\
\hline \multirow[t]{2}{*}{ July } & Average daily temperature $\left({ }^{\circ} \mathrm{C}\right)$ & 12.4 & 11.3 & 11.1 & 13.1 & 11.5 & 12.7 & 12.7 & 13.2 & 11.0 \\
\hline & Total monthly rainfall (mm) & 96 & 147 & 96 & 30 & 77 & 79 & 118 & 288 & 182 \\
\hline \multirow[t]{3}{*}{ August } & Average daily temperature $\left({ }^{\circ} \mathrm{C}\right)$ & 12.9 & 12.6 & 11.6 & 12.8 & 12.8 & 13.6 & 14.0 & 12.6 & 12.6 \\
\hline & Total monthly rainfall (mm) & 39 & 124 & 121 & 91 & 56 & 178 & 102 & 184 & 113 \\
\hline & Total winter rainfall (mm) & 520 & 526 & 515 & 418 & 427 & 375 & 449 & 790 & 619 \\
\hline
\end{tabular}

with dimethoate (see Table 3). During 2001 and 2002 the species was continuously grazed to the ground. This damage must have been caused by larger herbivores, selectively feeding on the grazing vetch.

The DMP of Vicia faba L. v. Fiord (faba bean) differed considerably between seasons (see Table 3) and was on average appreciably lower than that reported by Fourie et al. (2001). The performance of faba bean was exceptionally poor in the BB treatments during 1997 and 1999, despite the fact that the rainfall during both winters (see Table 4) exceeded the minimum of $350 \mathrm{~mm}$ deemed necessary for sufficient growth by Lochner (1989). The relatively cold average daily temperatures in April, combined with a relatively low rainfall during July (see Table 4), could, however, have had a negative effect on the performance of the cover crop in 1997. The application of P from 1998 onwards improved the DMP of faba bean initially (see Table 3). Faba bean germinated poorly during 1999 (visual observation). This might have been caused by soil-borne pests attacking the emerging seedlings. The performance of the plants that did germinate seemed to be further restricted by the absence of rain in June 1999, followed by a relatively dry July (see Table 4). Treatment of the seeds with dimethoate, as well as the application of $2.5 \mathrm{t} / \mathrm{ha}$ of calcitic lime during seedbed preparation, resulted in faba bean producing more than five $\mathrm{t} / \mathrm{ha}$ of dry matter at the end of August 2000 (see Table 3). The exceptionally high rainfall during July 2001 and 2002 compared to that of July 2000 (see Table 4) could have created conditions favourable for soil-borne diseases, which might have been responsible for the reduction in DMP during 2001 and 2002 compared to that of 2000 (see Table 3).

The DMP of Medicago scutellata (L.) Mill. v. Kelson ('Kelson' medic) and Medicago truncatula Gaertn. v. Paraggio ('Paraggio' medic) in the BB treatments from 1994 to 1996 (see Table 3) was similar to that reported by Fourie et al. (2001). The climatic conditions during 1997 (as described above), as well as the fact that the level of $\mathrm{P}$ in the $0-300 \mathrm{~mm}$ soil layer (see Table 2) was lower than the level deemed necessary for good growth rates with the Medicago species (De Ruiter, 1981; Sanderson, 1998), could have contributed towards the poor performance of the two Medicago species during that year. The application of $\mathrm{P}$ during seedbed preparation in 1998 improved the DMP of 'Kelson' medic and 'Paraggio' medic in the BB treatments by $38 \%$ and $260 \%$, respectively, compared to the DMP measured in these treatments in 1997 (see Table 3). This supported the results of Nnadi \& Haque (1988). The control of the pests must also have contributed towards the drastic increase in the DMP of 'Paraggio' medic. Despite the application of dimethoate and P, the species performed poorly during 1999 . Although the $\mathrm{pH}$ of the soil measured in 1999 was lower than that at the beginning of the trial (see Table 3), it still exceeded the minimum levels at which suppression of growth can be expected (Bordeleau \& Prévost, 1994; Evans et al., 1990; Helyar \& Anderson, 1971). Clarkson et al. (1987) reported that the amount of rainfall/irrigation received has a highly significant effect on the DMP of M. truncatula Gaertn v. Jemalong. The absence of rain in June 1999, followed by a relatively dry July, therefore, must have had a negative impact on the DMP of 'Paraggio' medic. The application of $2.5 \mathrm{t} / \mathrm{ha}$ of calcitic lime during seedbed preparation in 2000 approximately doubled the DMP of the two Medicago species, but could not restore it to the levels produced from 1994 to 1996 . This was probably the result of an increase in soil-borne diseases suffered by these two species after being planted on the same plots for 10 consecutive years in the absence of a rotation system with grain species (Lamprecht et al., 1988; Lamprecht et al., 1990).

The DMP of 'Woogenellup' subterranean clover followed much the same pattern as that of grazing vetch (see Table 3). The application of $2.5 \mathrm{t} / \mathrm{ha}$ of calcitic lime during seedbed preparation and the treatment of the seeds with dimethoate in 2000 improved its performance to the same levels produced in 1994. The reduction in DMP from 2000 to 2002 was probably due to an increase in soil-borne diseases against the species after using it on the same soil for 10 consecutive years. The exceptionally high rainfall 
measured during July 2001and 2002 compared to that of July 2000 might also have affected cover crop growth negatively.

In 1993, when the cover crops were sown as late as 24 May, the DMP of all the cover crops increased from the end of August to the end of November (see Table 5). If sown during early April, rye and 'Overberg' oats did not produce additional dry matter if left to die back naturally. Similar results were obtained with 'Saia' oats, with the exception of in 1998, when a considerable amount of additional growth took place from the end of August to the end of November. The lower rainfall during July and August 1998 compared to that of 1994, 1996, and 2000 (see Table 4) might have retarded growth during this period, resulting in more growth from September to November in order for the species to complete its life cycle. 'Kelson' medic produced significantly more dry matter from the end of August to mid-October/end of November, with the exception of 1994, if it was allowed to complete its life cycle (see Table 5). These results indicate that, in order to maximise DMP, 'Kelson' medic should rather be allowed to grow until mid-October than be controlled chemically at the end of August. Depending on the year, faba bean and, to a lesser extent, 'Paraggio' medic and grazing vetch, also produced more dry matter when not controlled chemically at the end of August.

\section{Potential of species to re-establish themselves}

'Paraggio' medic showed the potential to re-establish in the 1995 season, as indicated by the dry matter in the $\mathrm{AB}$ treatment being $33 \%$ of that measured in the BB treatment (see Table 3 ). The DMP of 1.19 t/ha (see Table 3 ) achieved with 81 viable seeds per square metre (see Fig. 1), was similar to that reported by Fourie et al. (2005). Both the total and viable amount of seeds did not increase from 1995 onwards (see Fig. 1). This could be attributed to the poor performance of the species during 1995 and 1997 in this treatment, due to poor re-establishment (see Table 3), as well as the less favourable climatic conditions during 1997, described previously (see Table 4), thereby not adding more seeds to the seedbed. The untimely germination of seeds during the summer could also have contributed to the observed decline. A large number of seeds were damaged during 1997 (see Fig. 1), probably by soil-borne pests. The inability of the species to re-establish at all during 1997 and 1999 (see Table 3) was probably due to the destruction of the germinating plants by soil-borne pests (Moulds, 1986; Porter, 1998). 'Kelson' medic, when left to die back naturally, produced considerably more seed than the seeding density used in the treatments in which the species were sown annually (see Fig. 1). Most of these seeds were, however, hardcoated, with too small a percentage being viable in any season. Similar to 'Paraggio' medic, both the total and viable amount of seed did not increase from 1996 onwards. This could be attributed to both the poor performance of the species during 1997, thereby failing to sustain the seedbed, as well as to the probability of untimely germination of seeds during summer. Although the amount of water the two Medicago species received in the present study exceeded that deemed necessary for re-establishment (Tadmor et al., 1971; Tadmor et al., 1974) the seed density could not reach the amounts deemed necessary for successful re-establishment (Carter \& Lake, 1985).

During 1999 the amount of viable seed produced by faba bean was $193 \%$ of the seeding density used in the treatment in which the species was sown annually (see Table 6). This resulted in the DMP of faba bean $(\mathrm{AB})$ being $172 \%$ compared with that of faba bean (BB) as determined at the end of August 1999 (see Table 3), indicating that the species had the ability to re-establish successfully in the short term. The DMP of grazing vetch (AB) was, however, only $22 \%$ compared with that of grazing vetch $(\mathrm{BB})$ at the end of August 1999 (see Table 3). This was despite the fact that the amount of viable seed produced was $50 \%$ of the seeding density used in the treatment in which the species was sown annually (see Fig. 2). These results indicated that the species would not be able to re-establish successfully under similar edaphic conditions. The inability of 'Woogenellup' subterranean clover to reestablish (see Table 3) was attributed to the species not producing significant amounts of viable seed over time. The considerable

\section{TABLE 5}

Percentage change in dry matter production (DMP) of the different cover crop species, from the end of August to the end of November, as determined in the treatments in which chemical control was applied at the end of November 1993 to 1998 , and in mid October 1999 to 2002 .

\begin{tabular}{|c|c|c|c|c|c|}
\hline \multirow{2}{*}{ Treatments } & \multicolumn{5}{|c|}{ Change in DMP } \\
\hline & $1993^{1}$ & $1994^{1}$ & $1996^{1}$ & $1998^{1}$ & $2000^{2}$ \\
\hline \multicolumn{6}{|l|}{ Grain species: } \\
\hline Secale cereale L. v. Henog (rye) & 231 & -40 & -67 & -58 & -42 \\
\hline Avena sativa L. v. Overberg ('Overberg’ oats) & 263 & -11 & 2 & -53 & -40 \\
\hline Avena strigosa L. v. Saia ('Saia' oats) & 451 & -13 & -6 & 171 & -38 \\
\hline \multicolumn{6}{|l|}{$\mathrm{N}$-fixing broadleaf species: } \\
\hline Vicia dasycarpa Ten. (grazing vetch) & 118 & -52 & -57 & 120 & -4 \\
\hline Vicia faba L. v. Fiord (faba bean) & 254 & -39 & -12 & 133 & 186 \\
\hline Medicago truncatula Gaertn v. Paraggio ('Paraggio' medic) & 242 & -15 & -2 & -24 & 116 \\
\hline Medicago scutellata (L.) Mill. v. Kelson ('Kelson’ medic) & 250 & -2 & 102 & 129 & 155 \\
\hline Trifolium subterraneum L. v. Woogenellup ('Woogenellup' subterranean clover) & 234 & -28 & 183 & -96 & 120 \\
\hline $\operatorname{LSD}(\mathrm{p} \leq 0.05)$ & 55 & 15 & 38 & 48 & 42 \\
\hline
\end{tabular}

${ }^{1}$ Cover crops controlled chemically end of November. ${ }^{2}$ Cover crops controlled chemically mid October. 
decline in the amount of seed from 1997 to 1999 (see Fig. 2) could be attributed to the poor performance of this cover crop in the $\mathrm{AB}$ treatment during this period (see Table 2). Damage to the seeds (see Fig. 2), probably caused by soil-borne pests, might have contributed to the reduction in the amount of seed.

The grain species could not re-establish successfully (see Table 2 ). Although the number of seeds present in 'Overberg' oats (AB) was as high as $60 \%$ of the seeding density used in the BB treatment of the species during 1995 (see Table 4), the species did not establish itself successfully (see Table 2). This was attributed to the fact that only a relatively small fraction of these seeds $(28 \%)$ was viable. The same phenomenon occurred in 'Saia' oats (AB) during 1995 and rye $(\mathrm{AB})$ during 1997. This supported the results of Fourie et al. (2005). The number of viable seeds present in these three AB treatments during 1999 indicated that no buildup of viable seed occurred over time (see Table 4). From 1999 onwards, the grain species were, therefore, sown in the AB treatments at the same seeding density used for the BB treatments.

\section{Control of winter growing weeds}

In the first year following the establishment of the vineyard in 1993, DMP of the winter growing weeds in the control and weeds (BB) treatments amounted to less than one t/ha (see Table 7). This suggested that the deep pre-plant soil preparation during 1992 could have had a negative impact on the weed seed population in the top soil. The DMP of the winter growing weeds measured in these two treatments during 1994 was an indication that the weeds in this region have the ability to re-establish successfully within two years after initial deep soil preparation. The sharp decline in DMP of winter growing weeds, measured in the control from 1994 to 1996, indicated that mechanical control, applied at the correct time from bud break to harvest, could reduce the stand of winter growing weeds in this region by as much as $73 \%$

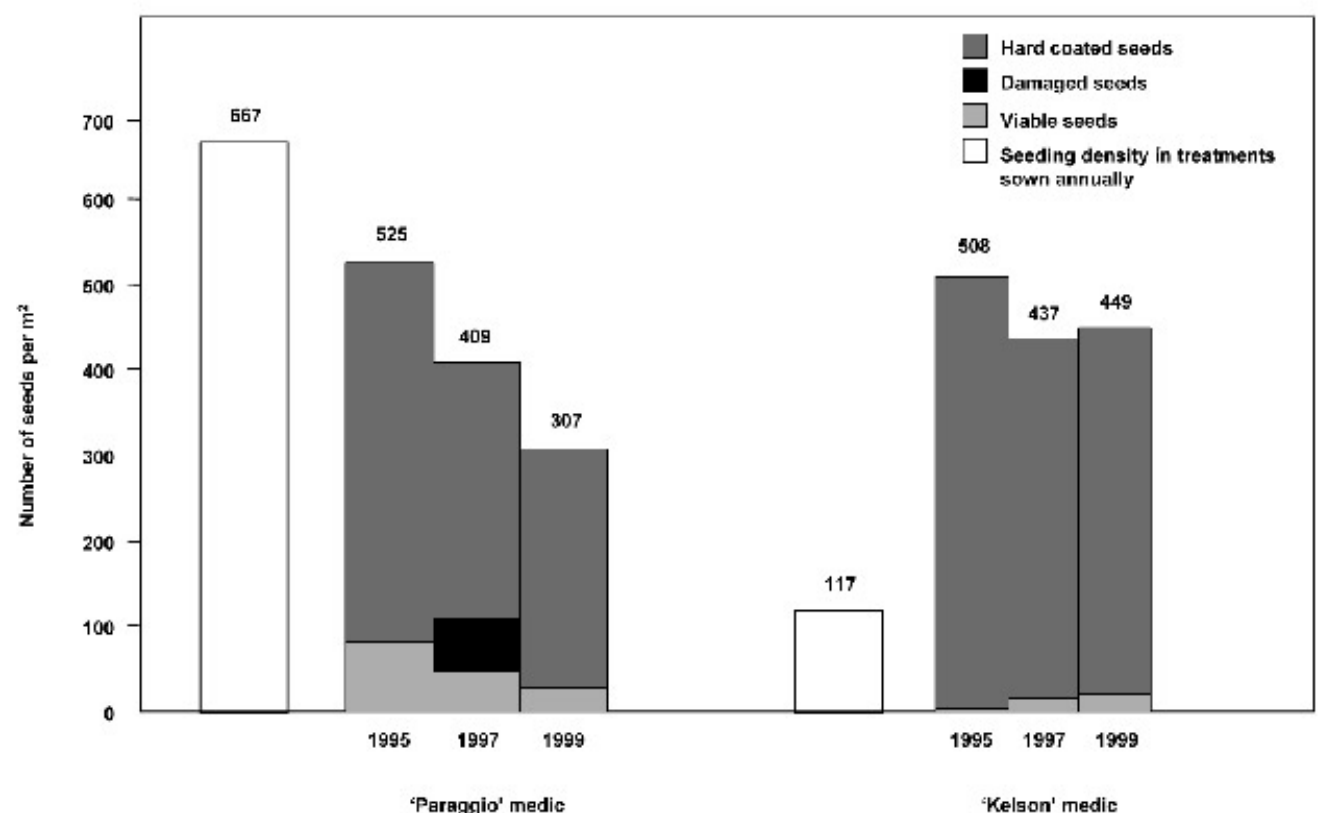

FIGURE 1

The number of seeds produced by Medicago truncatula Gaertn. v. Paraggio ('Paraggio' medic) and M. scutellata (L.) Mill. v. Kelson ('Kelson' medic) on a medium textured soil in Stellenbosch (Coastal wine grape region), if left to ripen.

TABLE 6

Number of seeds produced by the cover crop species over a period of six years on a medium textured soil near Stellenbosch (Coastal wine grape region), if left to ripen.

\begin{tabular}{|c|c|c|c|c|c|c|c|c|c|c|}
\hline \multirow[t]{3}{*}{ Species } & \multicolumn{10}{|c|}{ Number of seeds per $\mathbf{m}^{2}$} \\
\hline & \multirow{2}{*}{$\begin{array}{l}\text { Seeding } \\
\text { density }\end{array}$} & \multicolumn{3}{|c|}{1995} & \multicolumn{3}{|c|}{1997} & \multicolumn{3}{|c|}{1999} \\
\hline & & Total & Viable & Damaged & Total & Viable & Damaged & Total & Viable & Damaged \\
\hline \multicolumn{11}{|l|}{ Grain species: } \\
\hline Secale cereale L. v. Henog (rye) & 304 & 13 & 5 & 8 & 115 & 26 & 89 & 12 & 3 & 9 \\
\hline Avena sativa L. v. Overberg ('Overberg' oats) & 250 & 149 & 41 & 108 & 0 & 0 & 0 & 14 & 5 & 9 \\
\hline Avena strigosa L. v. Saia ('Saia' oats) & 468 & 73 & 10 & 63 & 0 & 0 & 0 & 7 & 0 & 7 \\
\hline \multicolumn{11}{|l|}{ N-fixing broadleaf species: } \\
\hline Vicia faba L. v. Fiord (faba bean) & 14 & 0 & 0 & 0 & 13 & 3 & 10 & 36 & 27 & 9 \\
\hline $\operatorname{LSD}(\mathrm{p} \leq 0.05)$ & & 224 & 23 & 13 & 139 & 54 & 65 & 77 & 25 & 6 \\
\hline
\end{tabular}




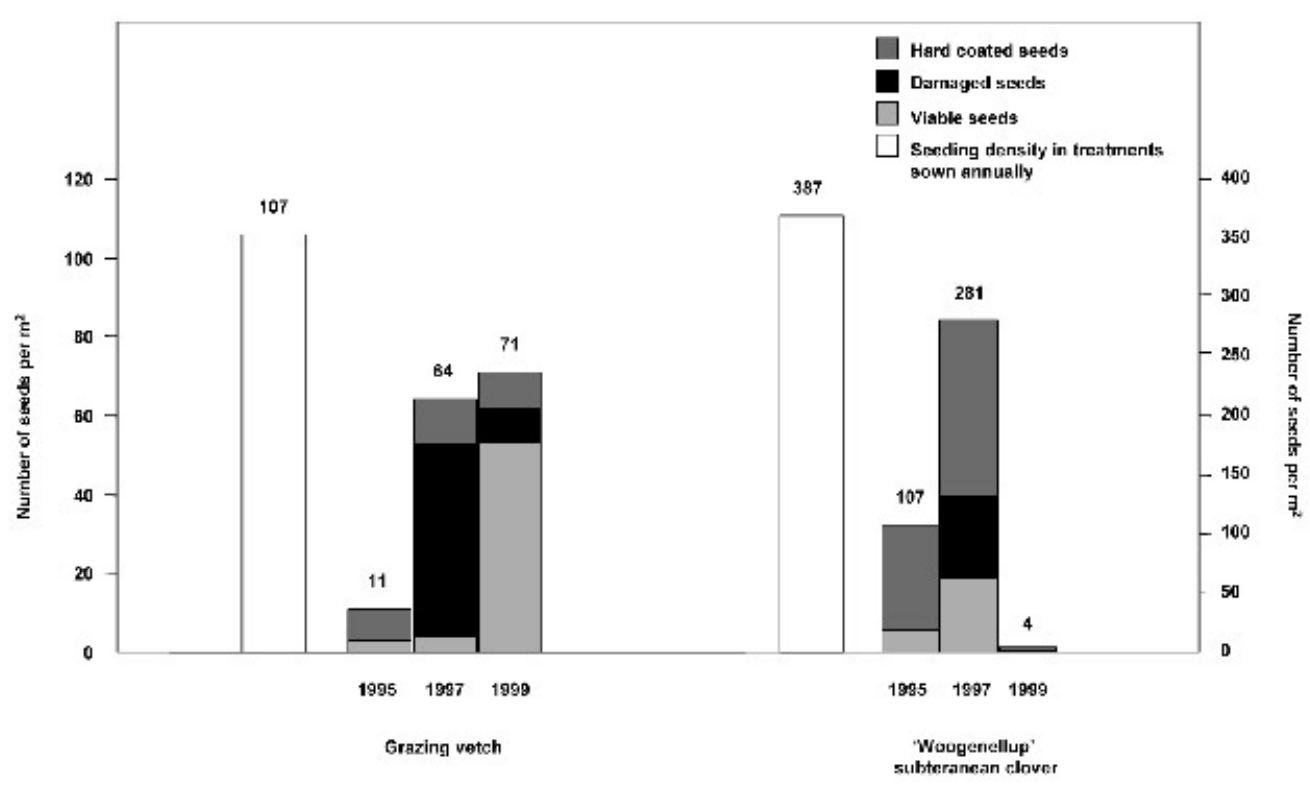

FIGURE 2

The number of seeds produced by Vicia dasycarpa Ten. (grazing vetch) and Trifolium subterraneum L. v. Woogenellup ('Woogenellup subterranean clover) on a medium textured soil in Stellenbosch (Coastal wine grape region), if left to ripen.

\section{TABLE 7}

Effect of two cover crop management practices, applied to three grain species and five $\mathrm{N}$-fixing broadleaf species, as well as two treatments in which no cover crops were sown and full surface chemical control and mechanical control was applied from bud break, respectively, on the dry matter production (DMP) of winter growing weeds, as measured end of August.

\begin{tabular}{|c|c|c|c|c|c|c|c|c|c|c|}
\hline \multirow{2}{*}{ Treatment } & \multicolumn{10}{|c|}{ DMP (t/ha) } \\
\hline & $1993^{1}$ & 1994 & 1995 & 1996 & 1997 & 1998 & 1999 & 2000 & 2001 & 2002 \\
\hline \multicolumn{11}{|l|}{ Grain species: } \\
\hline Secale cereale L. v. Henog (rye), $\mathrm{BB}^{2}$. & 0.08 & 1.11 & 0.94 & 0 & 0 & 0.12 & 0.87 & 0.52 & 0.24 & 0.65 \\
\hline Secale cereale $\mathrm{L}$. v. Henog (rye), $\mathrm{AB}^{3}$. & 0.20 & 1.10 & $3.87^{5}$ & 0 & $1.29^{5}$ & 1.40 & 1.22 & 0.20 & 0.85 & 0.76 \\
\hline Avena sativa L. v. Overberg ('Overberg' oats), BB. & 0.01 & 0.40 & 0 & 0 & 0 & 0.01 & 0 & 0.20 & 0 & 0 \\
\hline Avena sativa L. v. Overberg ('Overberg' oats), AB. & 0.06 & 0.54 & $3.34^{5}$ & 0 & $1.15^{5}$ & 1.24 & 0.55 & 0.30 & 0.23 & 0.97 \\
\hline Avena strigosa L. v. Saia ('Saia' oats), BB. & 0.03 & 0.79 & 0 & 0 & 0.06 & 0.08 & 0.33 & 0 & 0 & 0 \\
\hline Avena strigosa L. v. Saia ('Saia' oats), AB. & 0.01 & 0.82 & $4.21^{5}$ & 0 & $1.44^{5}$ & 0.26 & 0.02 & 0.62 & 0 & 0 \\
\hline \multicolumn{11}{|l|}{ N-fixing broadleaf species: } \\
\hline Vicia dasycarpa Ten. (grazing vetch),BB. & 0.15 & 0.81 & 0.45 & 1.22 & 1.24 & 0.54 & 0.94 & 0.38 & 0.49 & 1.04 \\
\hline Vicia dasycarpa Ten. (grazing vetch), AB. & 0.11 & 0.99 & $3.33^{5}$ & 1.07 & $1.80^{5}$ & 1.09 & $0.96^{5}$ & 0.87 & 0.98 & 1.39 \\
\hline Vicia faba L. v. Fiord (faba bean), BB. & 0.15 & 1.58 & 0.63 & 1.34 & 1.26 & 0.47 & 0.62 & 0.42 & 0.61 & 1.51 \\
\hline Vicia faba L. v. Fiord (faba bean), AB. & 0.15 & 1.84 & $3.67^{5}$ & 1.34 & $1.32^{5}$ & 0.63 & $1.63^{5}$ & 0.81 & 0.43 & 1.51 \\
\hline $\begin{array}{l}\text { Medicago truncatula Gaertn v. Paraggio } \\
\text { ('Paraggio' medic), BB. }\end{array}$ & 0.14 & 2.00 & 1.04 & 0.06 & 1.42 & 0.47 & 1.41 & 0.19 & 0.41 & 1.99 \\
\hline $\begin{array}{l}\text { Medicago truncatula Gaertn v. Paraggio } \\
\text { ('Paraggio' medic), AB. }\end{array}$ & 0.05 & 1.87 & $2.04^{5}$ & 0.51 & $1.15^{5}$ & 0.53 & $0.63^{5}$ & 0.64 & 0.32 & 1.50 \\
\hline $\begin{array}{l}\text { Medicago scutellata (L.) Mill. v. Kelson } \\
\text { ('Kelson' medic), BB. }\end{array}$ & 0.04 & 1.06 & 0.83 & 0 & 1.12 & 0.97 & 0.91 & 0.10 & 1.00 & 1.23 \\
\hline $\begin{array}{l}\text { Medicago scutellata (L.) Mill. v. Kelson } \\
\text { ('Kelson' medic), AB. }\end{array}$ & 0.10 & 0.66 & $2.89^{5}$ & 0.14 & $1.51^{5}$ & 0.87 & $0.69^{5}$ & 0.14 & 0.80 & 1.85 \\
\hline $\begin{array}{l}\text { Trifolium subterraneum L. v. Woogenellup } \\
\text { ('Woogenellup' subterranean clover), BB. }\end{array}$ & 0.02 & 1.45 & 1.65 & 0.34 & 1.57 & 0.60 & 0.26 & 0.30 & 1.13 & 0.64 \\
\hline $\begin{array}{l}\text { Trifolium subterraneum L. v. Woogenellup } \\
\text { ('Woogenellup' subterranean clover), AB. }\end{array}$ & 0.19 & 1.42 & $2.77^{5}$ & 0.91 & $1.41^{5}$ & 1.01 & $0.84^{5}$ & 0.50 & 1.12 & 1.51 \\
\hline Weeds, $\mathrm{MC}^{4}$ (Control). & 0.98 & 5.83 & 3.06 & 1.58 & 1.83 & 0.87 & 1.71 & 1.03 & 0.83 & 1.11 \\
\hline Weeds, BB. & 0.59 & 4.01 & 3.57 & 2.95 & 1.70 & 0.98 & 1.15 & 0.65 & 1.34 & 1.33 \\
\hline $\operatorname{LSD}(p \leq 0.05)$ & 0.20 & 2.29 & 1.83 & 1.11 & $\mathrm{NS}^{6}$ & 0.74 & NS & 0.67 & NS & 1.03 \\
\hline
\end{tabular}

${ }^{1}$ Cover crops established 24 May instead of early April. ${ }^{2} \mathrm{BB}=$ full surface post-emergence chemical control from just before bud break. ${ }^{3} \mathrm{AB}=$ full surface post-emergence chemical control from the end of November (1993 to 1998) and from mid October (1999 to 2002). ${ }^{4} \mathrm{MC}=$ chemical control in vine row, mechanical control in working row. ${ }^{5}$ Cover crop left to re-establish. ${ }^{6}$ Data do not differ significantly on the $5 \%$ level. 
within two seasons. The weed stand in the weeds (BB) treatment was reduced by 58\% within three seasons (from 1994 to 1997). The foregoing results indicated that a large number of the winter growing weed species must have been prevented from producing seeds, thereby reducing the amount of seeds available for germination in the following seasons.

Continuous effective suppression of the winter growing weeds (less than $20 \%$ of the weed stand in the control) was only achieved with the BB treatments of the two Avena species (see Table 7). Total suppression of the winter growing weeds was achieved with 'Overberg' oats (BB) and 'Saia' oats (BB) for six and five of the ten years, respectively. This enabled a 50\% reduction in the amount of glyphosate that was applied for post-emergence weed control at the end of August during those years. Although the winter weed suppression by rye (BB) was not effective in some years, total suppression of the winter growing weeds was nevertheless achieved during 1996 and 1997, while effective weed suppression occurred during 1993, 1994 and 1998. A DMP in excess of four t/ha by rye at the end of August 1994, 1995 and 1996 (see Table 2), combined with post-emergence chemical weed control during the first week of September, could have con- tributed towards the total weed suppression achieved with less than four t/ha of dry matter during 1997 (see Table 7). This was probably caused by the prevention of weed seed production during the first-mentioned seasons. The exceptionally high amounts of dry matter produced at the end of August by the grain species in the AB treatments during 1996 (see Table 3), prevented the winter growing weeds from germinating, although the weeds proliferated in these treatments during the previous winter (see Table 7). This indicated a high weed seed density in these treatments. 'Saia' oats sown annually from 1998 onwards, in combination with chemical control in mid October from 1999 onwards, resulted in total winter weed suppression in 2001 and 2002. This management practice could therefore be applied if 'Saia' oats is used as cover crop, without the danger of increasing the competition from winter growing weeds over time.

Grazing vetch (BB) competed effectively with the winter growing weeds during the first three seasons of the trial (see Table 7), with the DMP of the species still exceeding 2.5 t/ha if sown during April (see Table 3). 'Kelson' medic suppressed the winter growing weeds effectively in both the $\mathrm{BB}$ and $\mathrm{AB}$ treatments during 1993, 1994, 1996 and 2000 (see Table 7). This was achieved

\section{TABLE 8}

Effect of two cover crop management practices, applied to three grain species and five N-fixing broadleaf species, as well as two treatments in which no cover crop were sown and full surface chemical control and mechanical control was applied from bud break, respectively, on the dry matter production (DMP) of summer growing weeds, as measured at the end of November.

\begin{tabular}{|c|c|c|c|c|c|c|c|}
\hline \multirow[t]{2}{*}{ Treatment } & \multicolumn{7}{|c|}{ DMP (t/ha) } \\
\hline & $1993^{1}$ & 1994 & 1995 & 1996 & 1997 & 1998 & 2001 \\
\hline \multicolumn{8}{|l|}{ Grain species: } \\
\hline Secale cereale L. v. Henog (rye), $\mathrm{BB}^{2}$. & 0 & 0 & 0.22 & 0 & 0 & 0 & 0.06 \\
\hline Secale cereale $\mathrm{L} . \mathrm{v}$. Henog (rye), $\mathrm{AB}^{3}$. & 2.23 & 2.26 & $3.06^{5}$ & 1.83 & $2.72^{5}$ & 2.31 & 2.28 \\
\hline Avena sativa L. v. Overberg ('Overberg’ oats), BB. & 0 & 0 & 0.26 & 0 & 0 & 0 & 0.01 \\
\hline Avena sativa L. v. Overberg ('Overberg' oats), AB. & 0.66 & 0 & $3.84^{5}$ & 0.70 & $3.59^{5}$ & 1.24 & 0.46 \\
\hline Avena strigosa L. v. Saia ('Saia’ oats), BB. & 0.01 & 0 & 0.22 & 0 & 0 & 0.08 & 0 \\
\hline Avena strigosa L. v. Saia ('Saia' oats), AB. & 0.26 & 0.01 & $4.34^{5}$ & 0 & $0.95^{5}$ & 1.11 & 0.34 \\
\hline \multicolumn{8}{|l|}{ N-fixing broadleaf species: } \\
\hline Vicia dasycarpa Ten. (grazing vetch), BB. & 0.09 & 1.09 & 0.56 & 0.83 & 1.23 & 1.54 & 2.11 \\
\hline Vicia dasycarpa Ten. (grazing vetch), AB. & 1.25 & 4.37 & $2.92^{5}$ & 0.41 & $1.02^{5}$ & 1.56 & 0.96 \\
\hline Vicia faba L. v. Fiord (faba bean), BB. & 0.01 & 0.67 & 1.51 & 0.24 & 0.23 & 0.89 & 0.06 \\
\hline Vicia faba L. v. Fiord (faba bean), AB. & 0.38 & 2.13 & $3.78^{5}$ & 3.30 & $2.17^{5}$ & 1.10 & 0.58 \\
\hline $\begin{array}{l}\text { Medicago truncatula Gaertn v. Paraggio } \\
\text { ('Paraggio' medic), BB. }\end{array}$ & 1.19 & 0 & 0.63 & 0.78 & 0.27 & 0.75 & 0.47 \\
\hline $\begin{array}{l}\text { Medicago truncatula Gaertn v. Paraggio } \\
\text { ('Paraggio' medic), AB. }\end{array}$ & 2.30 & 3.19 & $5.69^{5}$ & 4.12 & $2.64^{5}$ & 2.38 & 1.32 \\
\hline $\begin{array}{l}\text { Medicago scutellata (L.) Mill. v. Kelson } \\
\text { ('Kelson' medic), BB. }\end{array}$ & 0.08 & 0 & 0.65 & 0.06 & 0.47 & 0.82 & 0.58 \\
\hline $\begin{array}{l}\text { Medicago scutellata (L.) Mill. v. Kelson } \\
\text { ('Kelson' medic), AB. }\end{array}$ & 1.40 & 2.07 & $2.57^{5}$ & 2.24 & $1.32^{5}$ & 2.18 & 0.26 \\
\hline $\begin{array}{l}\text { Trifolium subterraneum L. v. Woogenellup } \\
\text { ('Woogenellup' subterranean clover), BB. }\end{array}$ & 1.00 & 0.99 & 0.93 & 1.72 & 1.35 & 0.94 & 0.64 \\
\hline $\begin{array}{l}\text { Trifolium subterraneum L. v. Woogenellup } \\
\text { ('Woogenellup' subterranean clover), AB. }\end{array}$ & 1.26 & 3.99 & $3.69^{5}$ & 6.14 & $2.59^{5}$ & 2.99 & 1.13 \\
\hline Weeds, $\mathrm{MC}^{4}$ (Control). & 3.43 & 4.76 & 3.32 & 2.05 & 1.84 & 1.82 & 1.78 \\
\hline Weeds, BB. & 0.90 & 2.70 & 1.78 & 1.60 & 1.61 & 1.28 & 1.13 \\
\hline $\operatorname{LSD}(p \leq 0.05)$ & 2.40 & 1.94 & 2.34 & 3.11 & 1.45 & 1.59 & $\mathrm{NS}^{6}$ \\
\hline
\end{tabular}

${ }^{1}$ Cover crops established 24 May instead of early April. ${ }^{2} \mathrm{BB}=$ full surface post-emergence chemical control from just before bud break. ${ }^{3} \mathrm{AB}=$ full surface post-emergence chemical control from the end of November (1993 to 1998) and from mid October (2001). ${ }^{4} \mathrm{MC}=$ chemical control in vine row, mechanical control in working row. ${ }^{5}$ Cover crop left to re-establish itself on the AB treatments. ${ }^{6}$ Data do not differ significantly on the $5 \%$ level. 
from 1994 onwards with dry matter productions exceeding 2.3 t/ha (see Table 3). 'Paraggio' medic also showed the ability to effectively suppress the winter growing weeds during 1993, 1996 and 2000 (see Table 7). This did not, however, correspond with the DMP of the species (see Table 3).

\section{Control of summer growing weeds}

Long-term effective control of the summer growing weeds, as measured at the end of November, was achieved with the BB treatments of the grain species (Table 8). This was achieved with dry matter productions of 2.22, 3.60 and 3.26 t/ha for rye, 'Overberg' oats and 'Saia' oats, respectively. This was considerably lower than the 5 t/ha deemed necessary by Van Huyssteen et al. (1984) for effective season-long weed control in an intensively irrigated vineyard in the warmer Klein Karoo wine grape region of South Africa. Effective control was also achieved with the 'Saia' oats (AB) treatment during the 1993, 1994 and 1996 seasons and the 'Overberg' oats (AB) treatment during 1993 and 1994. The results indicated, however, that 'Saia' oats $(\mathrm{AB})$ and 'Overberg' oats $(\mathrm{AB})$ should not be applied for longer than two consecutive years, as it may allow the weeds to produce seeds and in doing so, promote a buildup in the weed population. No post-emergence weed control was necessary at the end of November in the treatments in which no summer weeds occurred. 'Overberg' oats (AB) and 'Saia' oats $(\mathrm{AB})$ were, therefore, managed without the application of any herbicides during 1994 and 1996, respectively.

The broadleaf species reduced the DMP of the summer growing weeds significantly over the long-term, if post-emergence chemical control was applied before bud break. Effective control was achieved in most years with the faba bean (BB) treatment. Initially, as well as when producing more than four tons of dry matter per ha (see Table 2), 'Kelson' medic (BB) suppressed the summer growing weeds effectively (see Table 8). Grazing vetch (BB) suppressed the summer weeds acceptably during the first three seasons only. Weed suppression with 'Paraggio' medic (BB) was erratic, with effective control being achieved during 1994, 1995 and 1997 only. 'Woogenellup' subterranean clover (BB) could not suppress the summer growing weeds effectively, although it reduced the DMP of the weeds significantly during the first three seasons.

\section{CONCLUSIONS}

None of the cover crop species could re-establish successfully under the conditions that prevailed during the trial. The grain species had the ability to produce significant amounts of dry matter over the long-term, despite the fact that they had been planted on the same soil for 10 consecutive years. The decline in DMP after four seasons, however, indicated that they should be rotated with other cover crop species. The grain species, with the exception of 'Saia' oats during one season, did not produce significantly more dry matter when left to complete their life cycles, if sown before mid April. It is, therefore, not worthwhile to allow these species to complete their life cycles if they were established before mid-April. The two oat species suppressed the winter growing weeds common to the Coastal grapevine region significantly, irrespective of the management practice applied. To achieve similar results with rye, however, post-emergence chemical control should be applied before bud break. To obtain effective suppression of the winter growing weeds in the region, the two oat species should be established annually and controlled chemically before bud break. The grain species controlled the summer growing weeds effectively if sown annually and controlled chemically before bud break. It seems, therefore, that this management practice should preferably be applied to the grain species on a well-drained, medium textured soil in this region.

'Woogenellup' subterranean clover should not be considered for cover crop management in this region. The other $\mathrm{N}$-fixing broadleaf species also performed poorly over the long-term on this medium textured soil. Faba bean, grazing vetch and the two Medicago species must not be established on the same soil for more than four consecutive years, since this would necessitate the use of additional chemicals as protection against pests and diseases. This defeats the purpose of reducing the use of chemicals in grapevine cultivation. The broadleaf species produced more dry matter if allowed to complete their life cycle, irrespective of seeding date. To achieve effective weed control with these species, however, post-emergence chemical control must be applied before bud break. The preference for the use of N-fixing broadleaf species in a rotation system with a grain species on medium textured soils in this region should be 'Kelson' medic > faba bean $>$ grazing vetch $>$ Paraggio medic.

\section{LITERATURE CITED}

Anonymous, 1997. Onkruide se weerstand teen middels wek kommer. Landbouweekblad 7 November, 95.

Bolland, M.D.A., 1997. Comparative phosphorous requirements of five annual medics. J. Plant Nutr. 20, 1029-1043.

Booysen, J.H., Steenkamp, J \& Archer, E., 1992. Names of vertical trellising systems (with abbreviations). Wynboer September, 15.

Bordeleau, L.M. \& Prévost, D., 1994. Nodulation and nitrogen fixation in extreme environments. Plant \& Soil 161, 115-125.

Buckerfield, J.C. \& Webster, K.A., 1996. Earthworms, mulching, soil moisture and grape yields. Wine Indust. J. 11, 47-53.

Carter, E.D. \& Lake, A., 1985. Seed, seedling and species dynamics of grazed annual pastures in South Australia. Proc. XV Inter. Grassl. Cong., 654-656. In: Brahim, K. \& Smith, S.E., 1993. Annual medic establishment and the potential for stand persistence in southern Arizona. J. Range Manage. 46, 21-25.

Clarkson, N.M., Chaplain, N.P. \& Fairbairn, M.L., 1987. Comparative effects of annual medics (Medicago spp.) and nitrogen fertilizer on the herbage yield and quality of subtropical grass pastures in southern inland Queensland. Austr. J. Exp. Agric. 27, 257-265.

Conradie, W.J., 1994. Wingerdbemesting. Handleiding van die werksessie oor wingerdbemesting, Nietvoorbij, 30 September, ARC Research Institute for Fruit, Vine and Wine, Private Bag X5026, Stellenbosch, 7600 R.S.A.

Cullen, J.M., Kable, P.F. \& Katt, M., 1973. Epidemic spread of a rust imported for biological control. Nature (London) 244, 462-463.

Daniel, J.T., Templeton, G.E., Smith, R.J \& Fox, W.T., 1973. Biological control of northern jointvetch in rice with an endemic fungal disease. Weed Sci. 21, 303-307.

De Ruiter, J.M., 1981. The phosphate response of eight Mediterranean annual and perennial legumes. N. Z. J. Agric. Res. 24, 33-36.

Evans, J., Dear, B. \& O'Connor, G.E., 1990. Influence of an acid soil on the herbage yield and nodulation of five annual pasture legumes. Austr. J. Exp. Agric. 30, 55-60.

Fourie, J.C., Louw, P.J.E. \& Agenbag, G.A., 2001. Effect of seeding date on the performance of grasses and broadleaf species evaluated for cover crop management in two winegrape regions of South Africa. S. Afr. J. Plant Soil 18, 118-127.

Fourie, J.C., Louw, P.J.E. \& Agenbag, G.A., 2005. The effect of cover crop management practices on the performance of selected grass and broadleaf species in a Sauvignon blanc/Ramsey vineyard in the semi-arid Olifants River Valley, South Africa. S. Afr. J. Enol. Vitic. 26, 131-139.

Helyar, K.R. \& Anderson, A.J., 1971. Effect of lime on growth of five species, on aluminium toxicity, and on phosphorous availability. Austr. J. Agric. Res. 22, 707-721. 
Henkes, R., 1997. Handling herbicide resistance. The Furrow 102, 8-11.

International Seed Testing Association, 1999. International rules for seed testing. Seed Sci. \& Technol. 27, Supplement, 174-182.

Khan, M.J., Monke, E.J. \& Foster G.R., 1986. Mulch cover and canopy effect on soil loss. Pap. ASAE no 86-253. Dept of Agric. Eng. Purdue Univ. West Lafayette, In. 47907, USA.

Lamprecht, S.C., Knox-Davies, P.S., Marasas, W.F.O. \& Calitz, F.J, 1988. Fungi associated with root rot of annual Medicago spp in South Africa. Phytophyl. 20, 281-286.

Lamprecht, S.C., Marasas, W.F.O., Knox-Davies, P.S. \& Calitz, F.J, 1990. Incidence of Fusarium species in different cropping systems of annual Medicago species and wheat. Phytophyl. 22, 69-76.

LeBaron, H.M., 1991. Distribution and seriousness of herbicide-resistant weed infestations worldwide. In: Caseley, J.C., Cussans, G.W. \& Atkin, R.K. (eds.). Herbicide resistance in weeds and crops. Butterworth-Heinemann, Boston. pp. 27-43.

Lochner, H., 1989. Blink toekoms vir fababone. Landbouweekblad, November, $12-15$.

Louw, P.J.E. \& Bennie, A.T.P., 1992. Water runoff and soil erosion in vineyard soils. Austr. Grapegrower \& Winemaker, Annual Technical Issue, 100-113.

Moulds, G.A., 1986. Cover crops are very beneficial. Austr. Grapegrower \& Winemaker 267, 12

Nnadi, L.A. \& Haque, I., 1988. Root nitrogen transformation and mineral composition in selected forage legumes. J. Agric. Sci. Camb. 111, 513-518.

Phatak, S.C., Sumner, D.R., Wells, H.D., Bell, D.K. \& Glaze, N.C., 1983. Biological control of yellow nutsedge with the indigenous rust fungus Piccinia canalicilata. Science 219, 1446-1448.

Porter, R., 1998. Establishing vineyard cover crops. Austr. Grapegrower \& Winemaker February, 13-18.

Putnam, A.R., 1990. Vegetable weed control with minimal herbicide inputs. HortScience 25, 155-159.
Radcliffe, D.E., Tollner, E.W., Hargrove, W.L., Clark, R.L. \& Colabi, M.H., 1988. Effect of tillage practices on infiltration and soil strength of a Typic Hapludult soil after ten years. Soil Sci. Soc. Am. J. 52, 798-804.

Roth, C.H., Meyer, B., Frede, G. \& Derpsch, R., 1988. Effect of mulch rates and tillage systems on infiltrabillity and other soil physical properties of an Oxisol in Parana, Brazil. Soil \& Tillage Res. 11, 81-91.

Sanderson, G., 1998. Medic cover crop dry matter production. Austr. Grapegrower \& Winemaker February, 22-25

SAS, 1990. SAS/STAT users guide, version 8, first edition, volume 2. SAS Institute Inc., Campus drive, Cary NC 27513

Shapiro, S.S. \& Wilk, M.B., 1965. An analyses of variance test for normality (complete samples). Biometrika 52, 591-611.

Tadmor, N.H., Eyal, E. \& Benjamin, R.W., 1974. Plant and sheep production on semi-arid annual grassland in Israel. J. Range Manage. 27, 427-432Tadmor, N.H., Shanan, L. \& Evenari, M., 1971. "Runoff farming" in the desert. V. persistence and yields of annual range species. Agron. J. 63, 91-95.

Tadmor, N.H., Shahan, L. \& Evenari, M., 1971. "Runoff farming" in the desert. V. persistence and yields of annual range species. Agron. J. 63, 91-95.

The Non-Affiliated Soil Analysis Work Committee, 1990. Handbook of standard soil testing methods for advisory purposes. Soil Sci. Soc. South Africa, P.O. Box 30030, Sunnyside, Pretoria.

Van Bosch, J. \& Pieterse, P.A., 1995. Invloed van verskillende peile van besproeiing op die droëmateriaalopbrengs van verskeie rog-, korog- en hawerkultivars in die Middelveld-bosveld van Transvaal. Toegepaste Plantwetenskap 9, 31-34.

Van Huyssteen, L., Van Zyl, J.L. \& Koen, A.P., 1984. The effect of cover crop management on soil conditions and weed control in a Colombar Vineyard in Oudtshoorn. S. Afr.J. Enol. Vitic. 5, 7-17.

Woodhead, S.H., 1981. Field efficacy of Phytophthora palmuvora, for control of milkweed vine. Phytopathol. 71, 913-916. 